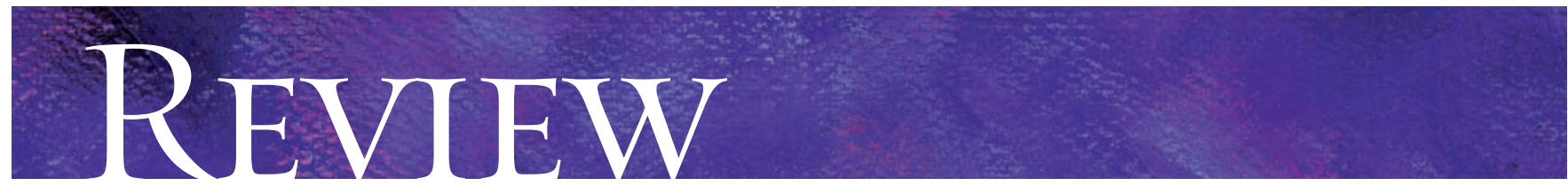

\title{
Parathyroid hormone for the treatment of osteoporosis: a systematic review
}

\author{
Ann Cranney, Alexandra Papaioannou, Nicole Zytaruk, David Hanley, Jonathan Adachi, \\ David Goltzman, Timothy Murray, Anthony Hodsman, for the Clinical Guidelines Committee \\ of Osteoporosis Canada
}

$\infty$

See related article page 48

\section{ABSTRACT}

Background: Human parathyroid hormone (hPTH)(1-34) was approved in 2004 for the treatment of severe osteoporosis. Members of the Osteoporosis Canada clinical guidelines committee conducted a systematic review of randomized controlled trials (RCTs) to assess the efficacy and safety of $\mathrm{hPTH}$ for fracture prevention in postmenopausal women and men with osteoporosis.

Methods: We searched MEDLINE, EMBASE, HTA, Current Contents and the Cochrane Controlled Trials Registry for published data from 1966 to February 2005. A systematic literature search for RCTs was conducted using the Cochrane Collaborative approach. We identified 12 trials that randomly assigned patients either to hPTH or placebo or to hPTH or an active comparator and were at least 1 year in duration. Outcomes included change in bone mineral density (BMD), fractures, back pain and adverse events. Two independent reviewers abstracted data on study characteristics and outcomes.

Results: hPTH(1-34) significantly increases lumbar spine $\mathrm{BMD}$, with smaller increases at the femoral neck and total hip. hPTH(1-84) significantly increases lumbar spine BMD. The data show a significant reduction in both vertebral and nonvertebral fractures with hPTH(1-34) in postmenopausal women with previous vertebral fractures. There were no data on fractures comparing the approved dose of hPTH(1-34) with active comparators.

Interpretation: There is Level I evidence that hPTH(1-34) significantly increases BMD at all skeletal sites except the radius and significantly reduces the risk of new vertebral and nonvertebral fractures in postmenopausal women with prior fractures.

CMAJ 2006;175(I):52-9

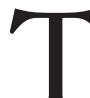

he 2002 Osteoporosis Canada clinical guidelines committee reviewed the evidence for several classes of drugs that reduce bone resorption and inhibit bone formation. ${ }^{1}$ Anabolic therapies are capable of inducing new bone formation through an increase in bone modelling and remodelling. ${ }^{2,3}$ Human parathyroid hormone (hPTH) is an 84-amino acid peptide hormone that plays a key role in the maintenance of calcium homeostasis. hPTH binds to a target cell surface G-protein-coupled hPTH/hPTHrP receptor, which results in activation of adenylate cyclase and phospholipases and increased intracellular levels of cyclic AMP and calcium. ${ }^{4}$ Intermittent hPTH given by subcutaneous injection has been shown to exert potent anabolic effects on the skeleton. ${ }^{5}$ hPTH increases the rate of bone remodelling and results in a positive remodelling balance, leading to thicker osteons (structural units of remodelled bone). ${ }^{6,7}$ New bone formation occurs on quiescent surfaces and, as a result, trabecular architecture comes to more closely resemble normal bone. ${ }^{8,9} \mathrm{hPTH}(\mathrm{I}-34)$ induces new periosteal bone apposition, which results in the enlargement of the outer circumference of tubular bones such as the radius. ${ }^{10}$ This bone apposition results from decreased osteoblast apoptosis and enhanced differentiation of osteoblasts from preosteoblasts. Bisphosphonates preserve existing skeletal microarchitecture but do not restore it toward a more normal structure. ${ }^{11,12}$ Increases in bone mass with bisphosphonates are most likely due to enhanced secondary mineralization of preformed osteons. ${ }^{13}$

Two forms of recombinant hPTH have been evaluated in clinical trials, hPTH(I-34) and the intact 84-amino acid form, $\mathrm{hPTH}(\mathrm{I}-84)$. hPTH(I-34) is approved for the treatment of severe osteoporosis. ${ }^{14} \mathrm{hPTH}(\mathrm{I}-84)$, although not currently approved, has been evaluated in clinical trials. ${ }^{15} \mathrm{hPTH}(\mathrm{I}-84)$ includes a $\mathrm{C}$ terminus, which may have discrete biologic properties and may therefore have different biologic actions from $\mathrm{hPTH}(\mathrm{I}-34))^{3,4}$

In this article we present the results of our systematic review of the literature on the efficacy and safety of hPTH therapy.

\section{Methods}

The hPTH working group included members of the Osteoporosis Canada Clinical Guidelines Committee and scientific consultants with Osteoporosis Canada who have expertise in hPTH or in clinical epidemiology or both. This 
review was approved by all members of the Clinical Guidelines Committee.

We included RCTs of at least I-year duration that compared hPTH with a placebo or with an active comparator and involved I of 3 distinct populations: postmenopausal women with osteoporosis, postmenopausal women with corticosteroid-induced osteoporosis or men with osteoporosis. The primary outcome was the effect of hPTH(I-34) or hPTH(I-84) on either bone mineral density (BMD) or fractures. Secondary outcomes were back pain and quality of life.

The Cochrane Collaborative approach for identifying RCTs guided our search strategy. ${ }^{16}$ We searched MEDLINE, EMBASE, HTA, Current Contents and the Cochrane Controlled Trials Registry from I966 to September 2005 (see online Appendix I, available at www.cmaj.ca/cgi/content/full /I75/I/52/DCI). Citations of relevant articles and reviews were examined to identify other potential trials. Two reviewers (A.C. and N.Z.) evaluated all titles and abstracts for eligibility. Full articles of relevant trials were obtained to make final judgments about inclusion.

The 2 reviewers independently abstracted data on study characteristics, results and methodologic quality. Data examined included study design, population, dose, treatment duration, percent change in BMD and the number of subjects with fractures. Volumetric BMD data and biochemical markers were not included as outcomes in this review, since they are not widely accepted as surrogate outcomes. Missing data were requested from study investigators or sponsors. We decided a priori not to pool the BMD and fracture data from the various trials since different hPTH preparations (i.e., hPTH[I-34] v. hPTH[I-84]) may have different modes of action, and doses may not be comparable. For example, $20 \mu \mathrm{g}$ of hPTH(I-34) may be roughly equivalent to $50 \mu \mathrm{g}$ of $\mathrm{hPTH}(\mathrm{I}-84)$ on a molar basis, but differences in peptide length may cause differences in tissue absorption or receptor activation. $^{4}$

RCTS were classified as level I (an RCT of adequate sample size, with blinding of subjects and assessors) or as level 2 (RCT that does not meet level I criteria, owing to a small sample or methodologic limitations).

\section{Results and interpretation}

A total of 655 potentially relevant citations were identified and screened (Fig. I). Of these, 24 were potentially eligible. Twelve trials were subsequently excluded: one included premenopausal women, ${ }^{17}$ Io were a duplicate report, companion or follow-up of a primary RCT, ${ }^{10,18-26}$ and in one BMD outcomes were for less than a year. ${ }^{27}$ Twelve published RCTs were included in this review. ${ }^{28-39}$ Nine trials involved postmenopausal women (Table I), ${ }^{28-34,38,39}$ of which one involved women with corticosteroid-induced osteoporosis (Table 2). ${ }^{34}$ Three trials involved men with osteoporosis (Table 3). ${ }^{35-37}$ Ten trials evaluated hPTH(I-34) $29-31,33-39$ and 2 trials hPTH(I-84). ${ }^{28,32}$

Two trials had losses to follow-up of over $20 \%,{ }^{29,33} 8$ trials had losses between $5 \%$ and 20\%, ${ }^{28,30,31,34,35,37-39}$ and 2 had less than $5 \% .{ }^{32,36}$ Allocation concealment was adequately reported in 2 trials ${ }^{30,39}$ and unclear in the remaining trials. Seven trials were double-blind..$^{28,31-33,36-38}$

\section{hPTH in postmenopausal women}

In a large trial comparing hPTH(I-34) with calcium and vitamin D among women with severe osteoporosis and prior fractures, Neer and associates found a significant reduction in new vertebral and nonvertebral fractures associated with hPTH (Table I and Table 4$).{ }^{31}$ With $20 \mu \mathrm{g}$ and $40 \mu \mathrm{g}$ of $\mathrm{hPTH}(\mathrm{I}-34)$ the relative risk $(\mathrm{RR})$ of new vertebral fractures was 0.35 (95\% confidence interval [CI] 0.22-0.55) and $0.3 \mathrm{I}$ (95\% CI 0.19-0.50) respectively (absolute risk reduction [ARR] 9\%-IO\%). Treatment with $20 \mu \mathrm{g} \mathrm{hPTH(I-34)} \mathrm{resulted}$ in a RR of 0.47 (95\% CI 0.25-0.88) for nonvertebral fractures and an ARR of $3 \%$. In other hPTH(I-34) trials, the absolute number of fractures was too small to achieve significance $e^{28,38,39}$ (Table 4). Body and associates found a reduction in nonvertebral fractures with $40 \mu \mathrm{g} / \mathrm{d} \mathrm{hPTH}(\mathrm{I}-34)$ compared with Io $\mathrm{mg} / \mathrm{d}$ alendronate (4.I\% v. $\mathrm{I} 3.7 \%, p=0.042){ }^{33}$

Six trials compared the effect of $\mathrm{hPTH}(\mathrm{I}-34)$ with placebo or an active comparator on BMD (Table 4 ). Doses of $\mathrm{hPTH}(\mathrm{I}-34)$ ranged from $20 \mu \mathrm{g} / \mathrm{d}$ to $50 \mu \mathrm{g} / \mathrm{d}$ and treatment durations from $\mathrm{I}$ to 3 years. There was a consistent increase in lumbar spine and femoral neck BMD but little effect on BMD at the distal radius. Increases in lumbar spine BMD with hPTH(I-34) were significant and ranged from $9.7 \%$ to $10.3 \%$ with $20 \mu \mathrm{g} / \mathrm{d}$ and from $\mathrm{I} 3.7 \%$ to $\mathrm{I} 4.3 \%$ with $40 \mu \mathrm{g} / \mathrm{d}$ (Table 4). Changes in femoral neck BMD were significant but

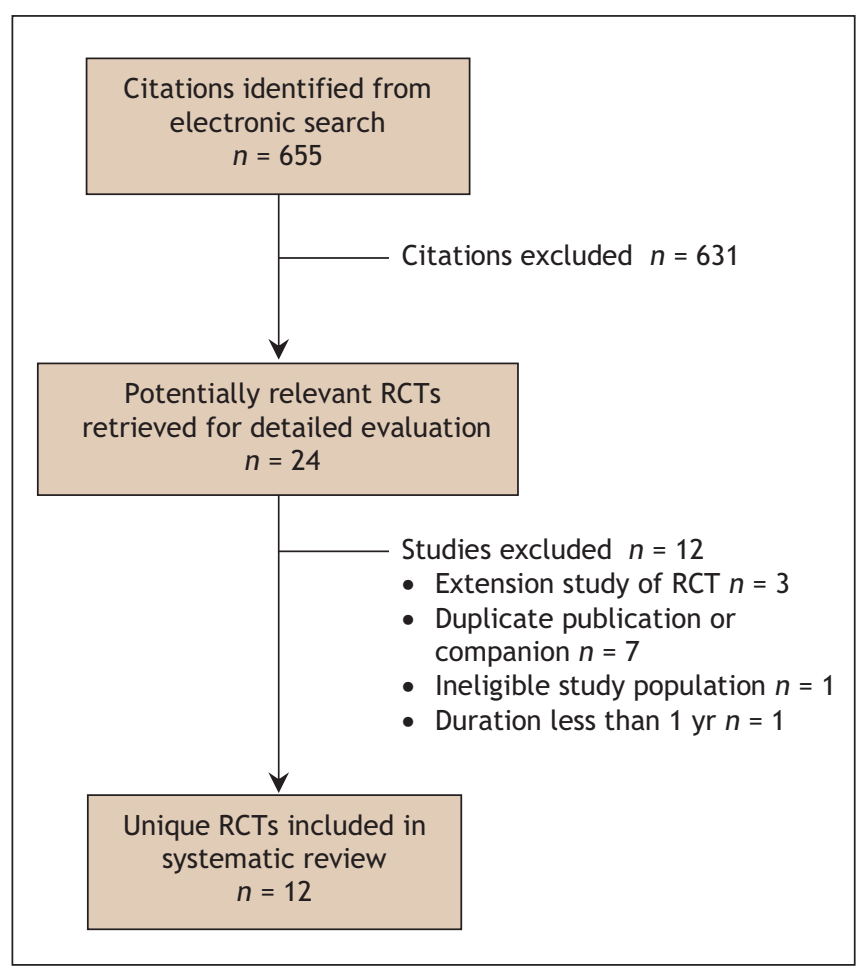

Fig. 1: Flow of articles through the systematic review. RCT = randomized controlled trial. 
smaller, ranging from $2.8 \%$ to $3.9 \%$ in the $20 \mu \mathrm{g} / \mathrm{d}$ group and $4.5 \%-5.1 \%$ in the $40 \mu \mathrm{g}$ group.

Two trials compared the effect of hPTH(I-84) with that of placebo or alendronate. Increases in lumbar spine BMD ranged from $6.3 \%$ to $7.8 \%$ after one year with $50-$ Ioo $\mu \mathrm{g}$ of hPTH(I-84), which were larger but not significantly different than increases seen with alendronate. ${ }^{28,32}$ Increases in femoral neck BMD with hPTH(I-84) were small compared with placebo and less than that seen with alendronate (Table 4).

\section{hPTH compared with bisphosphonates}

Two trials compared hPTH(I-34) $20 \mu \mathrm{g}$ or $40 \mu \mathrm{g}$ with alendronate $\mathrm{Io} \mathrm{mg} / \mathrm{d}$ in postmenopausal women. ${ }^{33,38}$ Body and associates compared $40 \mu \mathrm{g}$ of hPTH(I-34) with alendronate Io mg daily. Increases of lumbar spine and femoral neck BMD were greater with hPTH than with alendronate $(p<0.00 \mathrm{~s})$. At the ultradistal radius the increase with alendronate was $\mathrm{I} .4 \%$ compared with $0.23 \%$ with $40 \mu \mathrm{g} \mathrm{hPTH}(\mathrm{I}-34)(p<0.00 \mathrm{I}) .^{33}$

In a study by McClung and associates, hPTH(I-34) $20 \mu \mathrm{g} / \mathrm{d}$ resulted in significantly greater increases (I0.3\%) in lumbar spine BMD than with alendronate $10 \mathrm{mg} / \mathrm{d} .^{38}$

\section{Combination therapy}

Three trials evaluated hPTH therapy combined with either a bisphosphonate or calcitonin..$^{29,30,32}$ In an RCT involving 238 postmenopausal women with osteoporosis, alendronate combined with hPTH(I-84) did not result in larger increases in lumbar spine BMD than with hPTH alone. ${ }^{32}$ Cosman and associates compared the effect of hPTH(I-34) $25 \mu \mathrm{g}$ and hormone replacement therapy (HRT) with that of HRT alone in 52 postmenopausal women who had been taking HRT for at least a year. ${ }^{30}$ Three years of combination therapy resulted in increases in lumbar spine and total hip BMD of $13.4 \%$ and $4.4 \%$ respectively compared with a nonsignificant increase with HRT alone. ${ }^{30}$ In a small 2-year RCT, Hodsman and associates compared cyclical hPTH(I-34) $50 \mu \mathrm{g}$ followed by placebo calcitonin with hPTH followed by sequential salmon calcitonin (Table I). Combined sequential therapy with calcitonin did not offer any benefits for BMD over cyclical hPTH alone. ${ }^{29}$

Table 1: Characteristics of trials of human parathyroid hormone (hPTH) involving postmenopausal women

\begin{tabular}{|c|c|c|c|c|c|c|}
\hline Study & $\begin{array}{l}\text { No. of } \\
\text { patients } \\
\text { (treatment/ } \\
\text { control) }\end{array}$ & $\begin{array}{c}\text { Study } \\
\text { duration }\end{array}$ & Patient characteristics & Intervention & Outcome measures & $\begin{array}{l}\text { Loss to follow-up } \\
\text { and study } \\
\text { limitations }\end{array}$ \\
\hline $\begin{array}{l}\text { Hodsman } \\
\text { et al, }{ }^{28} \\
2003\end{array}$ & $\begin{array}{c}217 \\
(162 / 55)\end{array}$ & $1 \mathrm{yr}$ & $\begin{array}{l}\text { - Mean age } 64.5 \text { (SD 6.0) yr } \\
\text { - Postmenopausal } 18.2 \\
\text { (SD 7.3) yr } \\
\text { - Fracture prevalence 68.7\% } \\
\text { - T-score: LS -3.2 (SD 0.6), } \\
\text { FN -2.3 (SD 0.7) }\end{array}$ & $\begin{array}{l}\text { - hPTH(1-84), } 50 \mu \mathrm{g}, 75 \mu \mathrm{g} \\
\text { and } 100 \mu \mathrm{g} \text { subcutaneously } \\
\text { v. placebo daily } \\
\text { - Calcium } 500-1000 \mathrm{mg} / \mathrm{d} \text {, } \\
\text { vitamin D } 400 \mathrm{IU} / \mathrm{d}\end{array}$ & $\begin{array}{l}\text { BMD and BMC: LS, } \\
\text { FN, total hip and } \\
\text { total body }\end{array}$ & $\begin{array}{l}11 / 217(5.1 \%) \\
\text { lost to ITT } \\
\text { analysis, } 31 / 217 \\
(14.3 \%) \text { lost } \\
\text { overall } \\
\text { No fracture data }\end{array}$ \\
\hline $\begin{array}{l}\text { Cosman } \\
\text { et al, } \\
2001\end{array}$ & $\begin{array}{c}52 \\
(27 / 25)\end{array}$ & $3 \mathrm{yr}$ & $\begin{array}{l}\text { - Mean age } 60.2 \text { (SD 1.6) } \\
\text { yr } \\
\text { - Postmenopausal } 16.1 \\
\text { (SD 1.9) yr } \\
\text { - Fracture prevalence } \\
100 \% \\
\text { - T-score: LS < -2.5 }\end{array}$ & $\begin{array}{l}\text { - } \mathrm{hPTH}(1-34) 25 \mu \mathrm{g}+\mathrm{HRT} \mathrm{v} \text {. } \\
\text { HRT alone; HRT } 0.625 \mathrm{mg} \\
\text { Premarin or } 50 \mu \mathrm{g} \\
\text { Estraderm and } \\
5-10 \mathrm{mg} \text { progestin daily } \\
\text { for } 10 \mathrm{~d} \text { or } 2.5 \mathrm{mg} / \mathrm{d} \\
\text { - Calcium supplementation } \\
\text { to increase dietary intake } \\
\text { to } 1500 \mathrm{mg} / \mathrm{d} \text {, vitamin D } \\
400 \mathrm{IU} / \mathrm{d}\end{array}$ & $\begin{array}{l}\text { - BMD: LS, total hip } \\
\text { and total body } \\
\text { - BMC: total body } \\
\text { - Fractures: } \\
\text { vertebral and } \\
\text { nonvertebral }\end{array}$ & $\begin{array}{l}6 / 52(11.5 \%) \\
\text { Small sample }\end{array}$ \\
\hline $\begin{array}{l}\text { Neer et } \\
\mathrm{al}^{31} 2001\end{array}$ & $\begin{array}{c}1637 \\
(1093 / 544)\end{array}$ & $1.5 \mathrm{yr}$ & $\begin{array}{l}\text { - Mean age } 69.3 \text { (SD 7.0) } \\
\text { yr } \\
\text { - Postmenopausal } 21.0 \\
\text { (SD 8.3) yr } \\
\text { - Fracture prevalence } \\
\text { 100\% } \\
\text { - T-score: }-2.6\end{array}$ & $\begin{array}{l}\text { - Human recombinant } \\
\text { PTH(1-34) } 20 \mu \mathrm{g}, 40 \mu \mathrm{g} \text { v. } \\
\text { placebo } \\
\text { - Calcium } 1000 \mathrm{mg} / \mathrm{d} \text {, } \\
\text { vitamin D } 400-1200 \mathrm{IU} / \mathrm{d}\end{array}$ & $\begin{array}{l}\text { - BMD: LS, FN, } \\
\text { trochanter, total } \\
\text { hip, radius and } \\
\text { total body } \\
\text { - Fractures: } \\
\text { vertebral and } \\
\text { nonvertebral }\end{array}$ & $\begin{array}{l}311 / 1637 \\
(19.0 \%)\end{array}$ \\
\hline $\begin{array}{l}\text { Black et } \\
\text { al, }{ }^{32,41} \\
2003 / 2005\end{array}$ & $\begin{array}{c}238 \\
(178 / 60)\end{array}$ & $2 \mathrm{yr}$ & $\begin{array}{l}\text { - Mean age } 69.9 \text { (SD 7.1) } \\
\text { yr } \\
\text { - Postmenopausal } 22.7 \\
\text { (SD 6.3) yr } \\
\text { - Fracture prevalence } 47 \% \\
\text { - T-score: FN -2.2 } \\
\text { (SD 0.7) }\end{array}$ & $\begin{array}{l}\text { - hPTH(1-84) } 100 \mu \mathrm{g} \text { v. PTH } \\
100 \mu \mathrm{g}+\text { alendronate } \\
10 \mathrm{mg} \text { v. alendronate } \\
10 \mathrm{mg} \\
\text { - Calcium } 500 \mathrm{mg} / \mathrm{d} \text {, } \\
\text { multivitamin with } 400 \mathrm{IU} \\
\text { vitamin D }\end{array}$ & $\begin{array}{l}\text { - BMD: LS, FN, total } \\
\text { hip and } 1 / 3 \text { distal } \\
\text { radius } \\
\text { - Fracture: } \\
\text { nonvertebral }\end{array}$ & $\begin{array}{l}11 / 238(4.6 \%) \\
\text { Not powered } \\
\text { to evaluate } \\
\text { fractures }\end{array}$ \\
\hline
\end{tabular}




\section{hPTH therapy after prior bisphosphonate therapy}

Although the anabolic effects of hPTH may be accentuated if bone resorption is suppressed, there is concern that the decreased remodelling rates induced by bisphosphonates might impair the ability of hPTH to stimulate new bone formation. ${ }^{40}$ In contrast, Cosman and associates randomly assigned women who had previously taken alendronate to either cyclic or daily hPTH(I-34) in combination with alendronate or to alendronate alone. Significant increases in lumbar spine BMD of $6.1 \%$ and $5.4 \%$ were noted in the daily and cyclic treatment arms respectively. ${ }^{39}$

\section{Sequential use of bisphosphonate therapy after cessation of hPTH}

After hPTH(I-34) is discontinued, BMD declines; this loss can be prevented with sequential use of a bisphosphonate. ${ }^{18,23}$ In an RCT of hPTH(I-84) and alendronate, Black and associates randomly assigned women to receive a second year of either alendronate or placebo and found that the alendronate group had significant increases in lumbar spine BMD (4.9\%) compared with controls $(-1.7 \%)(p<0.01) .^{41}$

\section{Summary}

There is level I evidence that $\mathrm{hPTH}(\mathrm{I}-34) 20 \mu \mathrm{g} / \mathrm{d}$ and $40 \mu \mathrm{g} / \mathrm{d}$ increase BMD at the lumbar spine and proximal femur and decrease the risk of both vertebral and nonvertebral fractures in postmenopausal women with prior vertebral fractures. The effect of hPTH(I-34) on hip fractures has not been assessed. hPTH(I-34) results in larger increases in lumbar spine BMD than alendronate. There are no head-to-head fracture trials that compare the efficacy of $20 \mu \mathrm{g}$ of hPTH(I-34) to bisphosphonates in decreasing the risk of fracture.

There is level I evidence that $\mathrm{hPTH}(\mathrm{I}-84)$ increases lumbar spine BMD in postmenopausal women with osteoporosis.

The small increase in femoral neck BMD and decline in total body BMD may reflect a transient imbalance between cortical remodelling and bone formation. The decline in BMD at the distal radius seen in hPTH trials is not felt to be indicative of decreased bone strength and may occur as a result of the increased

Table 1: Characteristics of trials of human parathyroid hormone (hPTH) involving postmenopausal women (continued)

\begin{tabular}{|c|c|c|c|c|c|c|}
\hline Study & $\begin{array}{l}\text { No. of } \\
\text { patients } \\
\text { (treatment/ } \\
\text { control) }\end{array}$ & $\begin{array}{c}\text { Study } \\
\text { duration }\end{array}$ & Patient characteristics & Intervention & $\begin{array}{l}\text { Outcome } \\
\text { measures }\end{array}$ & $\begin{array}{l}\text { Loss to follow-up } \\
\text { and study } \\
\text { limitations }\end{array}$ \\
\hline $\begin{array}{l}\text { Body et } \\
\text { al, }^{33} 2002\end{array}$ & $\begin{array}{c}146 \\
(73 / 73)\end{array}$ & $14 \mathrm{mo}$ & $\begin{array}{l}\text { - Mean age } 65.5 \text { (SD 8.5) yr } \\
\text { - Postmenopausal } 18.5 \\
\text { (SD 9.5) yr } \\
\text { - T-score: FN -3.4 (SD 1.1) }\end{array}$ & $\begin{array}{l}\text { - hPTH(1-34) } 40 \mu \mathrm{g}+\text { placebo } \\
\text { tablet v. alendronate } \\
10 \mathrm{mg}+\text { placebo injection } \\
\text { - Calcium } 1000 \mathrm{mg} / \mathrm{d} \text {, } \\
\text { vitamin D } 400-1200 \mathrm{IU} / \mathrm{d}\end{array}$ & $\begin{array}{l}\text { - BMD/BMC: LS, } \\
\text { FN, } 1 / 3 \text { radius, } \\
\text { ultradistal radius } \\
\text { and total body } \\
\text { - Fracture: } \\
\text { nonvertebral } \\
\text { - Back pain }\end{array}$ & $\begin{array}{l}38 / 146(26.0 \%) \\
\text { Fractures were } \\
\text { secondary } \\
\text { outcome }\end{array}$ \\
\hline $\begin{array}{l}\text { Hodsman } \\
\text { et al, }{ }^{29} \\
1997\end{array}$ & 39 & $2 \mathrm{yr}$ & $\begin{array}{l}\text { - Mean age } 67.0 \text { (SD 8.0) yr } \\
\text { - Fracture prevalence } \\
100 \% \\
\text { - T-score: LS -3.3 (SD } \\
\text { 1.3), FN -3.3 (SD 1.1) }\end{array}$ & $\begin{array}{l}\text { - hPTH(1-34) sequential } 50 \mu \mathrm{g} \\
\text { (28 d) v. hPTH(1-34) } \\
\text { sequential } 50 \mu \mathrm{g}(28 \mathrm{~d})+ \\
\text { calcitonin } 75 \mu \mathrm{g}(42 \mathrm{~d}) \\
\text { - Calcium } 500 \mathrm{mg} / \mathrm{d}(20-\mathrm{d} \\
\text { cycles) }\end{array}$ & $\begin{array}{l}\text { - BMD: LS, FN } \\
\text { - Fractures: } \\
\text { vertebral and } \\
\text { nonvertebral }\end{array}$ & $\begin{array}{l}9 / 39(23.1 \%) \\
\text { Small sample }\end{array}$ \\
\hline $\begin{array}{l}\text { Cosman } \\
\text { et al, } \\
2005\end{array}$ & $\begin{array}{c}126 \\
(43 / 40 / 43)\end{array}$ & $15 \mathrm{mo}$ & $\begin{array}{l}\text { - Mean age } 68.4 \text { (SD 7.6) yr } \\
\text { - Postmenopausal } 20.8 \mathrm{yr} \\
\text { - Fracture prevalence } 48 \% \\
\text { - T-score: LS -2.9 (SD 0.9) }\end{array}$ & $\begin{array}{l}\text { - hPTH(1-34) } 25 \mu \mathrm{g} / \mathrm{d}+ \\
\text { alendronate } 70 \mathrm{mg} / \mathrm{wk} \mathrm{v} \text {. } \\
\text { hPTH(1-34) cyclic ( } 25 \mu \mathrm{g} / \mathrm{d} \\
\text { for } 3 \mathrm{mo} \text {, then none for } 3 \mathrm{mo} \text { ) } \\
\text { + alendronate } 70 \mathrm{mg} / \mathrm{wk} \mathrm{v} \text {. } \\
\text { alendronate } 70 \mathrm{mg} / \mathrm{wk} \\
\text { - Calcium supplementation for } \\
\text { total intake of } 1200-1500 \\
\text { mg/d, vitamin D } \\
\text { supplementation to increase } \\
25(\mathrm{OH}) \mathrm{D} \text { intake to }>50 \mathrm{nmol} / \mathrm{L}\end{array}$ & $\begin{array}{l}\text { - BMD: LS and } \\
\text { total hip } \\
\text { - Fractures: } \\
\text { vertebral and } \\
\text { clinical } \\
\text { nonvertebral }\end{array}$ & $\begin{array}{l}18 / 126(14.3 \%) \\
\text { Not powered to } \\
\text { evaluate fractures }\end{array}$ \\
\hline
\end{tabular}

Note: $\mathrm{SD}=$ standard deviation, $\mathrm{LS}=$ lumbar spine, $\mathrm{FN}=$ femoral neck, $\mathrm{BMD}=$ bone mineral density, $\mathrm{BMC}=$ bone mineral content, ITT = intention to treat, $\mathrm{HRT}=$ hormone replacement therapy. 
width of the radius. ${ }^{3}$ The absence of head-to-head fracture data suggests that hPTH(I-34) be limited to patients at high risk of fractures by virtue of very low BMD and pre-existing fractures.

There is level I evidence that combination therapy with alendronate and hPTH(I-84) may blunt the anabolic effect of hPTH on BMD. There are no fracture data comparing the effect of the combination of hPTH and alendronate with that of hPTH alone.

\section{hPTH(1-34) in postmenopausal women with corticosteroid-induced osteoporosis}

Lane and associates evaluated the effect of hPTH(I-34) in $5 \mathrm{I}$ postmenopausal women taking corticosteroids and HRT. Women were given hPTH(I-34) for one year and then fol- lowed for an additional year. hPTH(I-34) $25 \mu \mathrm{g}$ in combination with HRT increased BMD by $\mathrm{I} 2.6 \%$ at the lumbar spine and by $5.2 \%$ at the femoral neck after 2 years. ${ }^{34}$

\section{Summary}

There is level 2 evidence that hPTH(I-34) increases lumbar spine BMD in postmenopausal women with corticosteroid-induced osteoporosis. Fracture data are lacking in this population.

\section{hPTH(1-34) in men with osteoporosis}

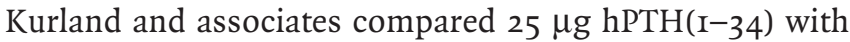
placebo in a small trial involving men with idiopathic os-

Table 2: Characteristics of trials of human parathyroid hormone (hPTH) involving men with osteoporosis

\begin{tabular}{|c|c|c|c|c|c|c|}
\hline Study & $\begin{array}{l}\text { No. of } \\
\text { patients } \\
\text { (treatment/ } \\
\text { control) }\end{array}$ & $\begin{array}{c}\text { Study } \\
\text { duration }\end{array}$ & Patient characteristics & Intervention & Outcome measures & $\begin{array}{l}\text { Loss to } \\
\text { follow-up }\end{array}$ \\
\hline $\begin{array}{l}\text { Kurland } \\
\text { et al, } \\
2000\end{array}$ & $\begin{array}{c}23 \\
(10 / 13)\end{array}$ & $1.5 \mathrm{yr}$ & $\begin{array}{l}\text { - Mean age } 51.7 \text { (SD 2.8) yr } \\
\text { - Fracture prevalence } 78 \% \\
\text { - T-score: LS <-2.5 }\end{array}$ & $\begin{array}{l}\text { - hPTH(1-34) } 25 \mu \mathrm{g} \mathrm{v} \text {. } \\
\text { placebo } \\
\text { - Calcium supplementation } \\
\text { to increase daily intake to } \\
1500 \mathrm{mg} \text {, vitamin D } \\
400 \mathrm{IU} / \mathrm{d}\end{array}$ & $\begin{array}{l}\text { - BMD: LS, FN, total hip } \\
\text { and } 1 / 3 \text { distal radius } \\
\text { - Fracture: vertebral }\end{array}$ & $0 / 23$ \\
\hline $\begin{array}{l}\text { Finkelstein } \\
\text { et al, } \\
2003\end{array}$ & $\begin{array}{c}83 \\
(27 / 28 / 28)\end{array}$ & $2 \mathrm{yr}$ & $\begin{array}{l}- \text { Mean age } 57.7 \text { (SD 8.0) yr } \\
\text { - T-score: LS or FN <-2.0 }\end{array}$ & $\begin{array}{l}\text { - hPTH(1-34) } 40 \mu \mathrm{g} \mathrm{v} \text {. } \\
\text { hPTH(1-34) } 40 \mu \mathrm{g}+ \\
\text { alendronate } 10 \mathrm{mg} \text { v. } \\
\text { alendronate } 10 \mathrm{mg} \text { alone } \\
\text { - Calcium supplementation } \\
\text { to increase daily intake to } \\
1000-1200 \mathrm{mg} \text {, vitamin D } \\
400 \mathrm{lU} / \mathrm{d}\end{array}$ & $\begin{array}{l}\text { - BMD: posterior-anterior } \\
\text { spine, lateral spine, FN, } \\
\text { total hip, radial shaft } \\
\text { and total body } \\
\text { - QCT: spine }\end{array}$ & $\begin{array}{c}10 / 83 \\
(12.0 \%)\end{array}$ \\
\hline $\begin{array}{l}\text { Orwoll et } \\
\text { al, }{ }^{37} 2003\end{array}$ & $\begin{array}{c}437 \\
(290 / 147)\end{array}$ & $11 \mathrm{mo}$ & $\begin{array}{l}\text { - Mean age } 58.6 \text { (SD 13.0) yr } \\
\text { - T-score: LS -2.2 (SD 1.2), } \\
\text { FN -2.7 (SD 0.8) }\end{array}$ & $\begin{array}{l}\text { - hPTH(1-34) } 20 \mu \mathrm{g} \text { and } \\
40 \mu \mathrm{g} \text { v. placebo } \\
\text { - Calcium } 1000 \mathrm{mg} / \mathrm{d} \text {, } \\
\text { vitamin D } 400-1200 \mathrm{IU} / \mathrm{d}\end{array}$ & $\begin{array}{l}\text { BMD: LS, FN, trochanter, } \\
\text { total hip, distal radius, } \\
\text { ultra-distal radius and } \\
\text { total body } \\
\text { - Fracture: nonvertebral }\end{array}$ & $\begin{array}{l}81 / 437 \\
(18.5 \%)\end{array}$ \\
\hline
\end{tabular}

Note: $\mathrm{SD}=$ standard deviation, $\mathrm{LS}=$ lumbar spine, $\mathrm{BMD}=$ bone mineral density, $\mathrm{SE}=$ standard error of the mean, FN $=$ femoral neck, $\mathrm{QCT}=$ quantitative computed tomography.

Table 3: Characteristics of trial of human parathyroid hormone (hPTH) involving postmenopausal women taking corticosteroid therapy

\begin{tabular}{|c|c|c|c|c|c|c|}
\hline Study & $\begin{array}{c}\text { No. of } \\
\text { patients } \\
\text { (treatment/ } \\
\text { control) }\end{array}$ & $\begin{array}{c}\text { Study } \\
\text { duration }\end{array}$ & Patient characteristics & Intervention & Outcome measures & $\begin{array}{l}\text { Loss to } \\
\text { follow-up }\end{array}$ \\
\hline $\begin{array}{l}\text { Lane et } \\
\mathrm{al}^{20,34} \\
1998 / 2000\end{array}$ & $\begin{array}{c}51 \\
(28 / 23)\end{array}$ & $2 \mathrm{yr}$ & $\begin{array}{l}\text { - Mean age 62.7 (SD 9.9) yr } \\
\text { - Postmenopausal 17.9 } \\
\text { (SD 9.9) yr } \\
\text { - Fracture prevalence } 27.5 \% \\
\text { - T-score: -2.8 (SD 0.17) }\end{array}$ & $\begin{array}{l}\text { - hPTH(1-34) } 25 \mu \mathrm{g}+\mathrm{HRT}+ \\
\text { prednisone v. HRT + } \\
\text { prednisone } \\
\text { - Calcium supplementation } \\
\text { to increase daily intake to } \\
1500 \mathrm{mg} \text {, and vitamin D } \\
800 \mathrm{lU} / \mathrm{d}\end{array}$ & $\begin{array}{l}\text { - BMD: LS, FN, } \\
\text { trochanter, total hip } \\
\text { and } 1 / 3 \text { distal radius } \\
\text { - Fractures: vertebral } \\
\text { and nonvertebral }\end{array}$ & $\begin{array}{c}3 / 51 \\
(5.9 \%)\end{array}$ \\
\hline
\end{tabular}

Note: $\mathrm{SD}=$ standard deviation, $\mathrm{LS}=$ lumbar spine, $\mathrm{HRT}=$ hormone replacement therapy, $\mathrm{BMD}=$ bone mineral density, $\mathrm{FN}=\mathrm{femoral}$ neck. 
teoporosis. After I8 months, BMD had increased significantly by $13.5 \%$ and $2.9 \%$ at the lumbar spine and femoral neck respectively. Total hip BMD did not change significantly, and there was a significant decrease at the $\mathrm{I} / 3$ distal radius (-I.2\%). ${ }^{36}$ Orwoll and associates, in an RCT involving 437 men with low BMD, compared $20 \mu \mathrm{g}$ or $40 \mu \mathrm{g}$ of $\mathrm{hPTH}(\mathrm{I}-34)$ with calcium and vitamin D. Of these men, $49 \%$ had hypogonadism. After one year, lumbar spine BMD increased by $5.4 \%$ with $20 \mu \mathrm{g}$ and by $8.5 \%$ with the $40 \mu \mathrm{g}$ dose compared with no change with placebo. There was a nonsignificant decrease in nonvertebral fractures with hPTH(I-34) compared with placebo. ${ }^{37}$ Finkelstein and associates compared hPTH(I-34) $40 \mu \mathrm{g}$ alone, $\mathrm{hPTH}(\mathrm{I}-34)$ with alendronate $\mathrm{Io} \mathrm{mg} / \mathrm{d}$, and alendronate alone. Increases in lumbar spine and femoral neck BMD were $18.1 \%$ and $9.7 \%$ respectively in group receiving $\mathrm{hPTH}(\mathrm{I}-34)$ alone compared with those taking combination $\mathrm{hPTH}(\mathrm{I}-34)$ and alendronate or alendronate alone $(p$ $<$ o.oor) (Table 4). ${ }^{35}$

\section{Summary}

There is level I evidence that hPTH(I-34) increases BMD at the lumbar spine and femoral neck in men with osteoporosis, but there is no data on fractures in this population.

\section{Health-related quality of life and back pain}

Neer and associates assessed health-related quality of life with both generic (Nottingham Health Profile) and disease-specific measures (Osteoporosis Assessment Questionnaire) (OPAQ). ${ }^{31}$ Using the OPAQ, fractures in a subgroup of 365 women were associated with a decline in health-related quality of life. However, there were no significant differences between patients taking $\mathrm{hPTH}(\mathrm{I}-34)$ and those taking placebo. ${ }^{42} \mathrm{Back}$ pain was reported in $3 \mathrm{hPTH}(\mathrm{I}-34)$ trials, ${ }^{31,33,38}$ and one trial had baseline and follow-up spine radiography. ${ }^{31}$ A significant reduction in back pain was seen among postmenopausal women in the fracture trial of $\mathrm{hPTH}(\mathrm{I}-34) \cdot{ }^{31} \mathrm{In} 2$ trials compar-

Table 4: Summary of results from randomized controlled trials of human parathyroid hormone (hPTH) on facture prevalence and bone mineral density (BMD)

\begin{tabular}{|c|c|c|c|c|c|c|c|c|}
\hline \multirow[b]{2}{*}{ Study } & \multirow{2}{*}{$\begin{array}{l}\text { hPTH dose } \\
\text { (type) }\end{array}$} & \multirow[b]{2}{*}{ Comparator } & \multirow{2}{*}{$\begin{array}{l}\text { Level of } \\
\text { evidence }\end{array}$} & \multicolumn{2}{|c|}{$\begin{array}{l}\text { Fractures, } \\
\text { treatment v. control, \% }\end{array}$} & \multicolumn{3}{|c|}{ BMD, treatment v. control, \% change } \\
\hline & & & & Vertebral & Nonvertebral & Lumbar spine & Femoral neck & Distal radius \\
\hline $\begin{array}{l}\text { McClung } \\
\text { et al, }{ }^{38} 2005\end{array}$ & $\begin{array}{l}20 \mu g \\
(1-34)\end{array}$ & Alendronate & 1 & NA & 8.8 v. 7.9 & 10.3 v. $5.5 \dagger$ & 3.9 v. 3.5 & NA \\
\hline $\begin{array}{l}\text { Cosman } \\
\text { et al, }{ }^{39} 2005\end{array}$ & $\begin{array}{l}25 \mu \mathrm{g} \\
(1-34)\end{array}$ & Alendronate & 2 & 3 v. 6 v. $11^{*}$ & $\begin{array}{l}10.5 \text { v. } 5.9 \\
\text { v. } 5.6^{*}\end{array}$ & $\begin{array}{l}6.1 \text { v. } 5.4 \\
\text { v. } \mathrm{NR}^{*} \dagger\end{array}$ & In graph only & NA \\
\hline $\begin{array}{l}\text { Body et al, } 33 \\
2002\end{array}$ & $\begin{array}{l}40 \mu g \\
(1-34)\end{array}$ & Alendronate & 1 & NA & 4.1 v. $13.7 \ddagger$ & 14.3 v. $6.4 \dagger$ & 4.5 v. $2.8 \dagger$ & 0 \\
\hline $\begin{array}{l}\text { Black et } \\
\text { al, }, 22,412003\end{array}$ & $\begin{array}{l}100 \mu \mathrm{g} \\
(1-84)\end{array}$ & Alendronate & 1 & NA & NA & $\begin{array}{l}6.3 \text { v. } 6.0 \\
\text { v. } 4.54 \S\end{array}$ & $\begin{array}{c}0.93 \text { v. } 1.85 \\
\text { v. } 2.45 \neq \S\end{array}$ & $\begin{array}{c}-3.45 \text { v. }-1.1 \neq \\
\text { v. }-0.75 \S\end{array}$ \\
\hline $\begin{array}{l}\text { Neer et al, }{ }^{31} \\
2001\end{array}$ & $\begin{array}{c}20-40 \mu \mathrm{g} \\
(1-34)\end{array}$ & Placebo & 1 & 5 v. $14.3+$ ๆ & 2.9 v. $6 \neq 9$ & $\begin{array}{c}13.7^{* *} \text { v. } 9.79 \\
\text { v. } 1.1 \dagger\end{array}$ & $\begin{array}{c}5.1^{* *} \text { v. } 2.8 \rrbracket \\
\text { v. }-0.7 \dagger\end{array}$ & -0.1 v. -1.6 \\
\hline $\begin{array}{l}\text { Cosman et } \\
\mathrm{al}^{30} 2001\end{array}$ & $\begin{array}{l}25 \mu g \\
(1-34)\end{array}$ & HRT & 2 & 0 v. 25 & NA & 13.4 v. $1.5 \dagger$ & 4.4 v. 1 & NA \\
\hline $\begin{array}{l}\text { Lane et al, }{ }^{20,34} \\
1998 / 2000\end{array}$ & $\begin{array}{l}25 \mu \mathrm{g} \\
(1-34)\end{array}$ & HRT & 2 & 0 v. 5.5 & 2.5 v. 11 & $\begin{array}{c}\text { At } 2 \text { yr: } 13.0 \\
\text { v. } 1.15 \dagger\end{array}$ & 4.7 v. $0 \neq$ & -3.3 v. 0 \\
\hline $\begin{array}{l}\text { Kurland } \\
\text { et al, }{ }^{36} 2000\end{array}$ & $\begin{array}{l}25 \mu g \\
(1-34)\end{array}$ & Placebo & 2 & 6.2 v. 16.6 & NA & 13.5 v. $0 \dagger$ & 2.9 v. $0 \ddagger$ & -1.2 v. $0.5 \neq$ \\
\hline $\begin{array}{l}\text { Orwoll } \\
\text { et al, }{ }^{37} 2003\end{array}$ & $\begin{array}{c}20-40 \mu g \\
(1-34)\end{array}$ & Placebo & 1 & NA & 1.3 v. 2 & $\begin{array}{c}9.039 \text { v. } 5.87^{* *} \\
\text { v. } 0.52 \dagger\end{array}$ & $\begin{array}{l}2.99 \text { v. } 1.5^{* *} \\
\quad \text { v. } 0.3 \ddagger\end{array}$ & -0.5 v. -0.15 \\
\hline $\begin{array}{l}\text { Finkelstein } \\
\text { et al, },^{35} 2003\end{array}$ & $\begin{array}{l}40 \mu \mathrm{g} \\
(1-34)\end{array}$ & Alendronate & 2 & NA & NA & $\begin{array}{l}18.1 \text { v. } 14.8 \\
\text { v. } 7.9 \dagger \S\end{array}$ & $\begin{array}{l}9.7 \text { v. } 6.2 \\
\text { v. } 3.2 \dagger \S\end{array}$ & $\begin{array}{l}-0.8 \text { v. } 1.0 \\
\text { v. } 1.0 \neq \S\end{array}$ \\
\hline
\end{tabular}

Note: $\mathrm{NA}=$ not assessed in the study, NR = not reported, HRT = hormone replacement therapy.

*hPTH (daily) + alendronate v. hPTH (cyclic) + alendronate v. alendronate alone.

$\uparrow p<0.001$.

$\neq p<0.05$.

ShPTH v. hPTH + alendronate v. alendronate alone.

१hPTH dose $=20 \mu \mathrm{g}$.

${ }^{* *} \mathrm{hPTH}$ dose $=40 \mu \mathrm{g}$. 
ing $\mathrm{hPTH}(\mathrm{I}-34)$ and alendronate Io $\mathrm{mg}, \mathrm{hPTH}(\mathrm{I}-34)$ was associated with a significant decrease in moderate to severe back pain. ${ }^{33,38} \mathrm{~A}$ meta-analysis of individual patient data from 5 trials comparing hPTH(I-34) with comparators found that patients taking $\mathrm{hPTH}(\mathrm{I}-34)$ had a reduced risk of back pain (pooled $\mathrm{RR}$ $0.60,95 \% \mathrm{CI} 0.55-0.80) .{ }^{43}$

\section{Summary}

There is no evidence of improved health-related quality of life associated with hPTH(I-34) or calcium with vitamin D in postmenopausal women with osteoporosis. There is level 2 evidence that back pain may be reduced in patients given hPTH(I-34).

\section{Adverse events}

A potential safety issue with $\mathrm{hPTH}(\mathrm{I}-34)$ is increased risk of osteosarcoma, which was reported in a life-long carcinogenicity study involving Fischer rats given high-dose $\mathrm{hPTH}(\mathrm{I}-34)$ from infancy through senescence ( 8 weeks of age through 2 years). ${ }^{44}$ Because of this unexpected finding, trials of $\mathrm{hPTH}(\mathrm{I}-34)$ for postmenopausal women with severe osteoporosis and men with osteoporosis ${ }^{31,33,37}$ were terminated prematurely by the sponsor. Osteosarcoma was found with all doses, and, in the lower-dose ranges, was first detected after about 20 months of therapy. There have been no reports of osteosarcoma in clinical trial subjects, and although there are isolated case reports of osteosarcoma in patients with long-standing hyperparathyroidism, there is no evidence to suggest that osteosarcoma is of increased frequency in hyperparathyroidism. ${ }^{45,46}$

Adverse events were included in all trials, but reporting was variable. Nine $\mathrm{hPTH}(\mathrm{I}-34)$ trials $^{29,31,33-39}$ reported postdose hypercalcemia (serum calcium level $>2.6 \mathrm{mmol} / \mathrm{L}$ ) that ranged from $3 \%$ to II \% among patients taking $20 \mu \mathrm{g}$ of $\mathrm{hPTH}(\mathrm{I}-34)$ and from $\mathrm{I} 6.8 \%$ to $38 \%$ among patients taking $40 \mu$ g compared with $\circ \%-3 \%$ among those taking the comparator. ${ }^{31,33}$ The overall pooled number of events of hypercalcemia was 282 in 1594 subjects from 7 trials. These episodes were mild: serum calcium levels usually returned to normal within 24 hours, and no clinical sequelae were reported in subjects with transient hypercalcemia. Hypercalcemia rates in the $\mathrm{hPTH}(\mathrm{I}-84)$ trials ranged from $\mathrm{I}_{2} \%$ to I5.6\%; there were 46 cases among patients taking hPTH out of a total of 340, compared with no cases among those taking the comparator..$^{28,32}$

Transient hypercalciuria (24-hour urine collection showing calcium level of $\geq 8 \mathrm{mmol} / \mathrm{d}$ or urine calcium/creatinine ratio > I.o) was reported in $6 \mathrm{hPTH}(\mathrm{I}-34)$ trials and ranged from o\% to Io\% difference between hPTH and comparator. . $^{29,31,33,35,37,39}$ There were no reported increases in renal stones.

A 10\% increase in serum creatinine levels was reported in one trial but did not exceed the normal range. ${ }^{29}$ In another trial, increases in creatinine clearance were reported with $\mathrm{hPTH}$ that were nonsignificant compared with increase seen with placebo. ${ }^{28}$

The frequency of headaches among treatment subjects in
$\mathrm{hPTH}(\mathrm{I}-34)$ trials ranged from $8 . \mathrm{I} \%$ to $10.8 \%$ and was not significantly greater than among control subjects. ${ }^{31,37}$

$\mathrm{hPTH}(\mathrm{I}-34) 20 \mu \mathrm{g}$ significantly increased the proportion of patients experiencing dizziness $(3 \%)^{31}$ and leg cramps (range $2 \%-8 \%,{ }^{31,33}$ with a higher proportion in the $40 \mu \mathrm{g}$ treatment arm. Hyperuricemia was reported in $2 \mathrm{hPTH}(\mathrm{I}-34)$ trials $^{31,37}$ and ranged from $0 \%$ to $3 \%$ of subjects. Hyperuricemia was associated with gout in 3 subjects taking $\mathrm{hPTH}(\mathrm{I}-84){ }^{32}$

The proportion of subjects with serious adverse events was not significantly different between treatment arms.

PTH treatment causes transient increases in serum calcium, but these episodes usually resolve. If they persist, they can be managed by decreasing calcium and vitamin D supplements.

This article has been peer reviewed.

From the Departments of Medicine of the University of Ottawa (Cranney), Ottawa; McMaster University (Papaioannou, Zytaruk, Adachi), Hamilton; University of Toronto (Murray), Toronto; and University of Western Ontario (Hodsman), London, Ont.; University of Calgary (Hanley), Calgary, Alta. (Hanley); and McGill University (Goltzman), Montréal, Que.

Competing interests: None declared for Nicole Zytaruk and David Goltzman. Ann Cranney has been a member of the medical advisory boards for Merck Frosst Canada and Zelos Therapeutics and has received speaker fees from Aventis, Procter \& Gamble Pharmaceuticals, Eli Lilly and Merck Frosst Canada. Alexandra Papaioannou has received speaker fees from Eli Lilly Canada, Novartis, Merck Frosst Canada, Amgen, Sanofi-Aventis and Procter \& Gamble Pharmaceuticals; she has received unrestricted educational grants from Eli Lilly Canada, Merck Frosst Canada, Sanofi-Aventis and Procter \& Gamble Pharmaceuticals. David Hanley has received an honorarium from Eli Lilly for being available for consultation during the past 2 years. He has participated in the major clinical trials of the 2 parathyroid hormone preparations that are either approved or under regulatory review for the treatment of osteoporosis; these trials were sponsored by the manufacturers, Eli Lilly and NPS Pharmaceuticals. David Hanley did not receive personal remuneration for his work as an investigator in these trials. He has been on the advisory board for the clinical trials conducted by NPS Pharmaceuticals and was a coauthor of the phase II and III clinical trial manuscripts for $\mathrm{hPTH}(\mathrm{I}-84)$ but did not receive personal remuneration for his authorship of these articles. He has received speaker fees from Eli Lilly and NPS Pharmaceuticals and honoraria for attendance at their advisory board meetings, some of which were held in association with major scientific conferences. Jonathan Adachi has been a consultant and speaker and has received honoraria and travel assistance from Astra Zeneca, Eli Lilly, GlaxoSmithKline, Merck Frosst, Novartis, NPS Allelix, Pfizer, Procter \& Gamble, Roche, Sanofi-Aventis, Servier and Wyeth. Timothy Murray has been a member of the advisory boards for NPS Pharmaceuticals, Eli Lilly Canada, Procter \& Gamble and Aventis and has received speaker fees from Eli Lilly Canada and Novartis. He has participated in clinical trials funded by Eli Lilly and Novartis but did not receive personal remuneration in connection with these grants and received an unrestricted educational grant from Merck Frosst. Anthony Hodsman is a member of the medical advisory boards of Eli Lilly Canada, Sanofi Aventis, Zelos Therapeutics, NPS Allelix, Novartis Canada, Servier Canada and Merck Frosst Canada. He has participated in clinical trials funded by Eli Lilly, Novartis, NPS Allelix, Sanofi Aventis and Zelos Therapeutics.

Contributors: Ann Cranney was involved in all phases of the review, including its design, literature search, and data extraction and interpretation, and was responsible for drafting the paper and incorporating revisions. Nicole Zytaruk was involved in reviewing the results of the literature search and in data extraction. Alexandra Papaioannou, David Hanley, Jonathan Adachi, Timothy Murray, David Goltzman and Anthony Hodsman were involved in the conception of the project and the interpretation of the data and results, and provided critical input on various drafts of the paper. All of the authors approved the final version of the manuscript and accompanying recommendations.

Acknowledgements: This work was funded by an unrestricted educational grant from Osteoporosis Canada. Ann Cranney is the recipient of a salary award from the Canadian Institutes of Health Research. 


\section{REFERENCES}

I. Brown JP, Josse RG; Scientific Advisory Council of the Osteoporosis Society of Canada. 2002 clinical practice guidelines for the diagnosis and management of osteoporosis in Canada. CMAJ 2002;2002:SI-34.

2. Riggs BL, Parfitt AM. Drugs used to treat osteoporosis: the critical need for a uniform nomenclature based on their action on bone remodeling. J Bone Miner Res 2005;20:177-84.

3. Hodsman AB, Bauer DC, Dempster DW, et al. Parathyroid hormone and teriparatide for the treatment of osteoporosis: a review of the evidence and suggested guidelines for its use. Endocr Rev 2005;26:688-703.

4. Murray TM, Rao LG, Diveti P, et al. Parathyroid hormone secretion and action: evidence for discrete receptors for the carboxyl-terminal region and related biological actions of carboxyl-terminal ligands. Endocr Rev 2005;26:78-II3.

5. Reeve J, Meunier PJ, Parsons JA, et al. Anabolic effect of human parathyroid hormone fragment on trabecular bone in involutional osteoporosis: a multicentre trial. BMJ I980;280:1340-4.

6. Bradbeer JN, Arlot ME, Meunier PJ, et al. Treatment of osteoporosis with parathyroid peptide (hPTH I-34) and oestrogen: increase in volumetric density of iliac cancellous bone may depend on reduced trabecular spacing as well as increased thickness of packets of newly formed bone. Clin Endocrinol (Oxf) 1992;37:282-9

7. Hodsman AB, Kisiel M, Adachi JD, et al. Histomorphometric evidence for increased bone turnover without change in cortical thickness or porosity after 2 years of cyclical hPTH(I-34) therapy in women with severe osteoporosis. Bone 2000;27:31I-8.

8. Hodsman AB, Steer BM. Early histomorphometric changes in response to parathyroid hormone therapy in osteoporosis: evidence for de novo bone formation on quiescent cancellous surfaces. Bone I993; I4:523-7.

9. Jiang Y, Zhao JJ, Mitlak BH, et al. Recombinant human parathyroid hormone [I34] [teriparatide] improves both cortical and cancellous bone structure. J Bone Miner Res 2003;I8:1932-4I.

Io. Zanchetta JR, Bogado CE, Ferretti JL, et al. Effects of teriparatide [recombinant human parathyroid hormone (I-34)] on cortical bone in postmenopausal women with osteoporosis. J Bone Miner Res 2003;18:539-43.

II. Dufresne TE, Chmielewski PE, Manhart MD, et al. Risedronate preserves bone architecture in early postmenopausal women in I year as measured by three-dimensional microcomputed tomography. Calcif Tissue Int 2003;73:423-32.

I2. Chavassieux PM, Arlot ME, Reda C, et al. Histomorphometric assessment of the long-term effects of alendronate on bone quality and remodelling in patients with osteoporosis. J Clin Invest 1997;100:1475-80.

13. Boivin GY, Chavassieux PM, Santora AC, et al. Alendronate increases bone strength by increasing the mean degree of mineralization of bone tissue in osteoporotic women. Bone 2000;27:687-94.

I4. Miller PD, Bilezikian JP, Deal C, et al. Clinical use of teriparatide in the real world: initial insights. Endocr Pract 2004;10:139-48.

15. Ettinger MP, Greenspan SL, Marriott TB, et al. PTH (I-84) prevents first vertebral fracture in postmenopausal women with osteoporosis. results from the TOP study. Arthritis Rheum 2004;50:4103.

I6. Dickersin K, Scherer R, Lefebvre C. Identifying relevant studies for systematic reviews. BMJ I994;309:I286-9I.

I7. Finkelstein JS, Klibanski A, Arnold AL, et al. Prevention of estrogen deficiency-related bone loss with human parathyroid hormone (I-34) a randomized controlled trial. JAMA 1998;280:1067-73.

I8. Rittmaster RS, Bolognese M, Ettinger MP, et al. Enhancement of bone mass in osteoporotic women with parathyroid hormone followed by alendronate. J Clin Endocrinol Metab 2000;85:2129-34.

I9. Rehman Q, Lang TF, Arnaud CD, et al. Daily treatment with parathyroid hormone is associated with an increase in vertebral cross-sectional area in postmenopausal women with glucocorticoid-induced osteoporosis. Osteoporos Int 2003;14:77-8I.

20. Lane NE, Sanchez S, Modin GW, et al. Parathyroid hormone treatment can reverse corticosteroid-induced osteoporosis. Results of a randomized controlled clinical trial. J Clin Invest I998;102:1627-33.

2I. Lindsay R, Nieves J, Formica C, et al. Randomised controlled study of effect of parathyroid hormone on vertebral-bone mass and fracture incidence among postmenopausal women on oestrogen with osteoporosis. Lancet I997;350:550-5.

22. Kaufman JM, Orwoll E, Goemaere S, et al. Teriparatide effects on vertebral fracture and bone mineral density in men with osteoporosis: treatment and discontinuation of therapy. Osteoporos Int 2005; 16:510-6.

23. Lindsay R, Scheele WH, Neer R, et al. Sustained vertebral fracture risk reduction after withdrawal of teriparatide in postmenopausal women with osteoporosis. Arch Intern Med 2004;164:2024-30.

24. Miller PD, Shergy WJ, Body JJ, et al. Rohe Me, Krege JH. Long term reduction of back pain risk in women with osteoporosis treated with teriparatide compared with alendronate. J Rheumatol 2005;32:1556-62.

25. Genant HK, Siris E, Crans GG, et al. Reduction in vertebral fracture risk in teriparatide-treated postmenopausal women as assessed by spinal deformity index. Bone 2005;37:170-4.

26. Genant HK, Halse J, Briney WG, et al. The effects of teriparatide on the incidence of back pain in postmenopausal women with osteoporosis. Curr Med Res Opin 2005;2I:1027-34.

27. Deal C, Omizo M, Schwartz EN, et al. Combination teriparatide and raloxifene therapy for postmenopausal osteoporosis: results form a 6-month double-blind placebo-controlled trial. J Bone Miner Res 2005;20:1905-II.
28. Hodsman AB, Hanley DA, Ettinger MP, et al. Efficacy and safety of human parathyroid hormone-(I-84) in increasing bone mineral density in postmenopausal osteoporosis. JClin Endocrinol Metab 2003;88:5212-20.

29. Hodsman AB, Fraher LJ, Watson PH, et al. A randomized controlled trial to compare the efficacy of cyclical parathyroid hormone versus cyclical parathyroid hormone and sequential calcitonin to improve bone mass in postmenopausal women with osteoporosis. J Clin Endocrinol Metab 1997;82:620-8.

30. Cosman F, Nieves J, Woelfert L, et al. Parathyroid hormone added to established hormone therapy: effects on vertebral fracture and maintenance of bone mass after parathyroid hormone withdrawal. J Bone Miner Res 2001;16:925-31.

3I. Neer RM, Arnaud CD, Zanchetta JR, et al. Effect of parathyroid hormone (I-34) on fractures and bone mineral density in postmenopausal women with osteoporosis. NEngl J Med 200I;344:1434-4I.

32. Black DM, Greenspan SL, Ensrud KE, et al. The effects of parathyroid hormone and alendronate alone or in combination in postmenopausal osteoporosis. $N$ Engl JMed 2003;349:1207-I5.

33. Body JJ, Gaich GA, Scheele WH, et al. A randomized double-blind trial to compare the efficacy of teriparatide [recombinant human parathyroid hormone (I-34)] with alendronate in postmenopausal women with osteoporosis. J Clin Endocrinol Metab 2002;87:4528-35.

34. Lane NE, Sanchez S, Modin GW, et al. Bone mass continues to increase at the hip after parathyroid hormone treatment is discontinued in glucocorticoid-induced osteoporosis: results of a randomized controlled clinical trial. J Bone Miner Res 2000;15:944-5I.

35. Finkelstein JS, Hayes A, Hunzelman JL, et al. The effects of parathyroid hormone, alendronate, or both in men with osteoporosis. N Engl JMed 2003;349:1216-26.

36. Kurland ES, Cosman F, McMahon DJ, et al. Parathyroid hormone as a therapy for idiopathic osteoporosis in men: effects on bone mineral density and bone markers. J Clin Endocrinol Metab 2000;85:3069-76.

37. Orwoll ES, Scheele WH, Paul S, et al. The effect of teriparatide (human parathyroid hormone [I-34]) therapy on bone density in men with osteoporosis. J Bone Miner Res 2003;18:9-17.

38. McClung M, Miller P, Civitelli R, et al. Differential effects of teriparatide and alendronate on markers of bone remodeling and areal and volumetric bone density in women with osteoporosis. Arch Intern Med 2005;165:1762-8.

39. Cosman F, Nieves J, Zion M, et al. Daily and cyclic parathyroid hormone in women receiving alendronate. $N$ Engl J Med 2005;353:566-75.

40. Ettinger B, San Martin J, Crans G, et al. Differential effects of teriparatide on BMD after treatment with raloxifene or alendronate. J Bone Miner Res 2004;19:745-5I.

4I. Black DM, Bilezikian JP, Ensrud K, et al. One year of alendronate after one year of PTH [I-84] for osteoporosis. N Engl J Med 2005;353:555-65.

42. Oglesby AK, Minshall ME, Shen W, et al. The impact of incident vertebral and nonvertebral fragility fractures on health-related quality of life in established postmenopausal osteoporosis: results from the teriparatide randomized, placebo-controlled trial in postmenopausal women. JRheumatol 2003;30:1579-83.

43. Nevitt MC, Chen P, Dore RK, et al.. Reduced risk of back pain following teriparatide treatment: a meta-analysis. Osteoporosis Int 2005;17:273-80.

44. Vahle JL, Sato M, Long GG, et al. Skeletal changes in rats given daily subcutaneous injections of recombinant human parathyroid hormone(I-34) for 2 years and relevance to human safety. Toxicol Pathol 2002;30:312-21.

45. Betancourt M, Wirfel KL, Raymond AK, et al. Osteosarcoma of bone in a patient with primary hyperparathyroidism: a case report. J Bone Miner Res 2003;18:163-6.

46. Palmer M, Adami HO, Krusemo YB, et al. Increased risk of malignant diseases after surgery for primary hyperparathyroidism: a nationwide cohort study. Am J Epidemiol I988;127:103 I-40.

Correspondence to: Dr. Ann Cranney, Ottawa Hospital, Civic Campus, Clinical Epidemiology Program, 1053 Carling Ave., Ottawa ON KIY 4E9; fax 6I3 76I-5492

\section{Members of the Clinical Guidelines Committee of Osteoporosis} Canada: Alexandra Papaioannou (chair), Department of Medicine, McMaster University, Hamilton, Ont.; Jacques Brown, Department of Medicine, Laval University, Québec, Que.; Angela Cheung, Department of Medicine, University of Toronto, Toronto; Ann Cranney, Department of Medicine, University of Ottawa, Ottawa, Ont.; Gillian Hawker, Department of Medicine, University of Toronto, Toronto, Ont.; Anthony Hodsman, Department of Medicine, University of Western Ontario, London, Ont.; Sophie Jamal, Department of Medicine, University of Toronto, Toronto, Ont.; Brent Kvern, Department of Family Medicine, University of Manitoba, Winnipeg, Man.; William Leslie, Department of Medicine, University of Manitoba, Winnipeg, Man.; Kerry Siminoski, University of Alberta, Edmonton, Alta. 